\title{
The Mystery of the Lord's Nativity in the Sermons of Leo the Great ${ }^{1}$
}

The Mystery of the Lord's Nativity lies in the centre of Christian spirituality. Despite the fact that Christmas remains one of the least understood celebrations of the western civilisation. Paraphrasing the words of Karl Rahner - every year boils down to a number of similar rituals: some Christmas mood, pious or humanitarian clichés, a bunch of presents, and then things return to normal. Every Christian is obliged to try to resist the magic of Christmas. ${ }^{2}$ This fact does not seem surprising if we consider how few theological publications there are concerning the birth of Christ, especially if we compare it to other events of the salvation history, e.g. Calvary or the empty grave.

\footnotetext{
${ }^{1}$ Source text of the Sermons of Leo the Great used in the article: Sancti Leonis Magni, Romani pontificis, opera omnia, vol. 1, accurante J.-P. Migne, Parisiis 1846, 141-468 (Patrologiae Cursus Completup. Series Latina, 54); Sancti Leonis Magni, Romani pontificis, tractatus septem et nonaginta [Tractatus 1-38], recensuit A. Chavasse, Turnholti 1973 (Corpus Christianorum. Series Latina, 138); Léon le Grand, Sermons, vol. 1, Paris $1964^{2}$ (Sources Chrétiennes, 22 bis) and its English translations: The Letters and Sermons of Leo the Great, Bishop of Rome, translated, with introduction, notes, and indices by C. Lett Feltoe, Grand Rapids [2004] (A Select Library of Nicene and post-Nicene Fathers of the Christian Church. Second series, 12) [Sermons XXI-XXIV, XXVI-XXVIII, XXXI, XXXIII, XXXVI]; Select Sermons of S. Leo the Great on the Incarnation, translated, with notes by W. Bright, London 1886 [Sermon LXVI].

${ }^{2}$ Cf. K. Rahner, Bóg stał się człowiekiem, przekł. M. Węcławski, Poznań 1978, p. 53.
} 
It was different in the times of the Church Fathers. Theology of incarnation was constantly present in the thought of the ancient Church, despite the fact that many of the fathers were not even familiar with the Feast of the Nativity, e.g. Justin Martyr or Irenaeus. The incredible passion, love and hope with which generations of theologians drew from biblical records, constantly inspires and encourages to reflect on the great mystery of faith in different shades of Christian pilgrimage.

A true promoter of the mystery of Nativity was Pope Leo I, also known as Saint Leo the Great. His pontificate took place in the difficult times of barbarian invasions of Italy. In the context of his theological and cultural formation, Saint Leo proved to be a truly unique person with broad intellectual horizons. His charism of a shepherd, fully devoted to serving the Church, made him the one disseminating Christian teachings and participating in the creation of the new civilisation of Europe. We know much about Pope Leo's activity thanks to his incredibly beautiful sermons written in Latin, about a hundred of which have been preserved, and thanks to his letters (about one hundred and fifty). Among his sermons the ones that interest us the most are: on the Feast of the Nativity (11 sermons) and on the Feast of the Epiphany (8 sermons). On the basis of these source texts we shall try to elaborate on the main thoughts concerning the mystery of the Nativity. First we shall discuss the spiritual aspects of the mystery of incarnation, then we shall present the Lord's coming as the epiphany of God's Grace, and lastly we shall indicate the attitude one should adopt towards the Mystery of the Birth of Christ.

\section{Joy and Light - the Fruits of the Nativity of the Lord ${ }^{3}$}

Saint Leo begins his first sermon on the Feast of the Nativity during his pontificate with the following words: "Our Saviour, dearly-beloved,

${ }^{3}$ Cf. L. Pidolle, S. Léon, chantre de l'humble et sublime mystère de Noél, "Connaissance des Pères de l'Eglise" 115 (2009), p. 40-58. 
was born today: let us be glad. For there is no proper place for sadness, when we keep the birthday of the Life, which destroys the fear of mortality and brings to us the joy of promised eternity. No one is kept from sharing in this happiness. There is for all one common measure of joy, because as our Lord the destroyer of sin and death finds none free from charge, so is He come to free us all. Let the saint exult in that he draws near to victory. Let the sinner be glad in that he is invited to pardon. Let the gentile take courage in that he is called to life." ${ }^{4}$

The author of Sermons very often urges his listeners to go through the time of Christmas in a joyful way, since the time of our Saviour's birth is our chance for eternal life, liberation from the fear of death and liberation from sin for all men. Christ's birth brings reward for the saint, forgiveness for the sinners and light for those who live in the darkness of death. He encourages us in joyful celebration of the day, which he calls the day of salvation: "Let us be glad in the Lord, dearly-beloved, and rejoice with spiritual joy that there has dawned for us the day of ever-new redemption, of ancient preparation , of eternal bliss."

The joy of the Lord's arrival reveals divine greatness and glory, but at the same time shows the enormous love the Creator has for his humble creatures: "Let the righteous then rejoice in the LORD, and let the hearts of believers turn to GOD'S praise, and the sons of men confess His wondrous acts; since in this work of GOD especially our humble estate realizes how highly its Maker values it."

The fruit of God's love is the joy radiant with the Light of Christ. The day of His Birth is a day to rejoice, as the Light of His Epiphany is shining upon us. Born of a Virgin, made Himself visible to the world. ${ }^{7}$

The author mentions that although all God's epiphanies are a reason to "rejoice in the Lord always" (Phil 4:4), the Nativity of the Lord inclines us to spiritual joy even more, as it shines brighter than on any other day. For Leo the Great Christmas is a celebration radiant with Light. This Light is

\footnotetext{
${ }^{4}$ Sermon XXI (On the Feast of the Nativity I), 1, p. 220.

${ }^{5}$ Sermon XXII (On the Feast of the Nativity II), 1, p. 222.

${ }^{6}$ Sermon XXIV (On the Feast of the Nativity IV), 2, p. 229.

${ }^{7}$ Cf. Sermon XXXII (On the Feast of the Epiphany II).
} 
the deity of Jesus Christ, "God from God, Light from Light, true God from true God" - as the Nicene Creed proclaims. Following Depositio martyrum ${ }^{8}$ one can assume that Christmas was introduced into the liturgical calendar about $330 \mathrm{AD}$ in Rome as the confirmation of accepting the decisions of the Council of Nicaea by the Church in Rome. The Council was a reaction to the heresy of Arianism, ${ }^{9}$ that is why the expression "of one Being (homoousios) with the Father" appeared in the Nicene Creed. In Sermon XXV on the Feast of the Nativity Leo confirmed it by reminding that: the Son of God is the Light that looked upon the blind "and veiled with his body the splendor of his majesty." ${ }^{10}$ Therefore, the Light itself cannot be separated from its source: "since the splendor born from a light is not posterior to the light, and the true light was never lacking its splendor, the substantial always having its shining, just as the substantial always has its existing. But the manifestation of this splendor is called mission, by which Christ appeared to the world. [...] As has been written, 'To those who sat in darkness and in the shadow of death, a light has shone."

The Church chose 25 December to celebrate Christmas because calendar time corresponds with the "rebirth" of the sun after the winter solstice. What the Church saw in this sign was the rebirth of the One, who became true Light. Saint Leo encourages then: "Confine the material light to your bodily senses, and with all your mental powers embrace that 'true light which lighteth every man that cometh into this world,' (Jn 1:9) and of which the prophet says, 'Come unto Him and be enlightened, and your faces shall not blush' (Ps 34:5)."

Quoting the words of Christ: "Do not think that I have come to abolish the law or the prophets. I have come not to abolish but to fulfil" (Mt 5:17),

${ }^{8}$ The earliest information comes from Depositio martyrum dated back to $354 \mathrm{AD}$, and written about 20 years earlier (335-336).

${ }^{9}$ Heresy negating consubstantiality and co-equality of the three persons of the Trinity as well as Christ's deity.

${ }^{10}$ Sermon XXV (On the Feast of the Nativity V), 2; http://www.pathsoflove.com/ blog/2009/12/christmas-sermon-25-of-leo-the-great (10 Sept. 2013)

${ }^{11}$ Ibidem 3.

${ }^{12}$ Sermon XXVII (On the Feast of the Nativity VII), 6, p. 236. 
Leo refers to the fulfilment of the New Testament in Jesus Christ, who became the light of truth. It is true that the Old Testament heralded His presence in the prophets' teachings, however, the fulfilment of time was accomplished in the birth of Jesus as man. ${ }^{13}$ In His divine goodness "His mercy has imparted many gifts of His providence [...] when in Christ the very Mercy has descended to sinners, the very Truth to those that are astray, the very Life to those that are dead." ${ }^{4}$ The Light of the Gospel presents itself as lumen veritatis, ${ }^{15}$ that comes to "scatter the darkness of human ignorance." ${ }^{16}$ Saint Leo often presents Christ as the Truth, which brings complete liberation from ignorance and lies. These earthly errors and conflicting notions by a falsely-called science according to Leo come from "the craft of misleading demons." ${ }^{17}$ As Leo indicates in his sermon on the Feast of the Epiphany the lack of truth is the worst form of famine humans can suffer: "He, the Bread of Life and the Food of reason that came down from heaven, removed that worse than all famines under which the Egyptians' minds were labouring, the lack of truth." ${ }^{18}$

Every man can look for the truth and find it, just like these three men who "follow the leading of the light above, and with steadfast gaze obeying the indications of the guiding splendour, are led to the recognition of the Truth by the brilliance of Grace." ${ }^{19}$ How great their joy must have been that from their original bond and from earthly errors they could be called to eternal bliss. ${ }^{20}$ Men should therefore accept with faith this divine Light, the Truth that "came down from heaven" for our salvation.

\section{${ }^{13}$ Cf. Sermon XXV, 4.}

${ }^{14}$ Sermon XXIV, 1, p. 229.

${ }^{15}$ Cf. ibidem 5, p. 231; Sermon XXV, 4; Sermon XXIX (On the Feast of the Nativity IX), 2; Sermon XXX, 1. The expressions lumen veritatis and lux veritatis appear 11 times in the sermons and splendor veritatis is used once: Sermon XXVIII (On the Feast of the Epiphany VIII), 2.

\footnotetext{
${ }^{16}$ Sermon XXV, 1.

${ }^{17}$ Sermon XXIII (On the Feast of the Nativity III), 3, p. 227.

${ }^{18}$ Sermon XXXIII (On the Feast of the Epiphany III), 4, p. 247.

${ }^{19}$ Sermon XXXI (On the Feast of the Epiphany I), 2, p. 244.

${ }^{20}$ Cf. Sermon XXIII, 3, p. 227.
} 
Saint Leo constantly encourages believers to have faith in the power of the Lord's coming.

Pope Leo also preaches that men's acceptance of the miracle of the Saviour's Nativity is already a gift of God, and that the sign that led the wise men from the far East with such strength and splendour, was the expression of divine grace itself. ${ }^{21}$

That is why the holy liturgy is a privileged occasion to experience the light of the grace of the Nativity. Through the proclamation of the Gospel the act of the Mystery of Salvation is made present and revealed in this divine miracle. ${ }^{22}$ For Salvation, as Pope Leo indicates, comes to man in the sacramentum of the Word: "And are to be regarded as having made no slight progress, who entertain no doubt as to what they have heard, so that even if they cannot, as yet, clearly apprehend some Scriptural mystery, they still most firmly believe that in the Divine books there is no falsehood." 23 The Lord's coming is expressed in the liturgy by yearly celebrations of Christmas: "for as the year rolls round, there recurs for us the commemoration of our salvation [...]; on which we are bound with hearts up-lifted to adore the divine mystery: so that what is the effect of GOD'S great gift may be celebrated by the Church's great rejoicings." ${ }^{24}$

\section{Lord's Nativity as the Epiphany of God's Devotion}

Contrary to Leo's sermons on Lent, sermons on the Feast of the Nativity touch on various topics. Leo does not focus on Christ's birth only, he tries to place it in a greater, broader context.

\footnotetext{
${ }^{21}$ Cf. Sermon XXXV (On the Feast of the Epiphany V), 1.

${ }^{22}$ Ibidem.

${ }^{23}$ Sermon LXVI (On the Passion XV), 1, p. 58.

${ }^{24}$ Sermon XXII, 1, p. 222.
} 


\section{1. "Undeniably great is the mystery of devotion" (1 Tim $3: 16$ )}

When Leo the Great encourages believers to discover the gift of the mystery of incarnation, he emphasises that God's grace and devotion are of crucial importance in the process. Coming to this world Christ fulfilled the promises of the Old Testament, and, as we have mentioned before, brought the plenitude of gifts of the New Testament. Consequently, Leo talks about Christ being a sacrament, a sign of grace, quoting the words of Paul the Apostle: "et manifeste magnum est pietatis sacramentum quod manifestatum est in carne iustificatum est in spiritu apparuit angelis praedicatum est gentibus creditum est in mundo adsumptum est in gloria" (1 Tim 3:16 Vulgate). Similarly to other Latin Fathers, Pope Leo adopts and spreads the use of the word "mystery" (sacramentum) to refer to important events in Christ's life and liturgical celebrations. ${ }^{25}$ Saint Augustine also uses the term sacramenta to refer to liturgical celebrations of the Church, but he does that less frequently than Pope Leo. ${ }^{26}$

Christmas is therefore a mystery, "the great mystery of devotion," the completion of which is Easter - the mystery of God's grace for the salvation of the world: "the Son of God, begotten before the ages by the Father, and eternal with the Father and co-eternal in con-substantial equality, came into this world through the womb of the Virgin in this sacrament of chosen tenderness, in which and from which 'Wisdom has built herself a home' (Prov 9:1), and the unchangeable Divinity of the Word fitted for itself the form of a slave, in the likeness of sinful flesh." ${ }^{27}$

Following Paul the Apostle, Saint Leo attributes the words "the great mystery of devotion" to Christ and his mystery of salvation, which is continued in the Church. He stresses the mystery of God's grace even more by the use of the word pietas, which has a second meaning in Leo's

${ }^{25}$ Cf. J. De Ghellinck, Pour l'histoire du mot « sacramentum », [in:] Les Anténicéens, vol. 1, Louvain-Paris 1924, p. 16-17.

${ }^{26}$ Cf. G. Hudon, Les présupposés sacramentals de saint Léon le Grand, "Église et Théologie » 10 (1979), p. 339-340.

${ }^{27}$ Sermon XXV, 2. 
writings - it refers to God's mercy on His people. ${ }^{28}$ That is one of the reasons why Pope Leo is often perceived as the apostle and the proclaimer of God's grace, which was revealed in the Mystery of the Incarnation. ${ }^{29}$

With reference to Paul the Apostle (1 Tim 3:16 and Phil) we can notice that Leo the Great does not separate these two mysteries, the Mystery of the Incarnation and the Resurrection, as "the Only-Begotten Son of God undertook by a single inclination of his majesty both the will to be born as a human being and the ability to be killed by human beings."30

\subsection{The Self-Abatement of the Son of God}

Saint Leo never stops praising the humble and at the same time sublime coming of the Lord. He particularly admires the Lord's self-abatement, which brings His mercy to men. Raising man to God's dignity (including the fact that God created man in his image), surprises him less than the fact that the Lord took on Him man's nature and the form of a servant. ${ }^{31}$ Human sight would not have endured, had the Son of God revealed Himself in the full splendour of His majesty. To the same human nature to which it was said: "Thou art earth, and unto earth shalt thou go," the following words were addressed: 'sit Thou on My right hand." According to Leo a believer dwells "on nothing more frequently and more trustingly than on the fact that GOD the Son of GOD, begotten of the co-eternal Father, was also born by a human birth." ${ }^{2}$

Although in the times before the birth of Christ God bestowed numerous gifts upon mankind, the nativity of Jesus brought an even greater gift - mercy. Although in the form of a slave He was made man, both natures

${ }^{28}$ Pietas means "piety" or "devotion" to God, but can also be used to describe His attributes, namely love and mercy; cf. A. Guillaume, Prière, jeûne et charité: des perspectives chrétiennes et une espérance pour notre temps, Paris 1985, p. 67.

${ }^{29}$ Cf. Sermon XLVII (On Lent IX), 2.

${ }^{30}$ Sermon XXXVII (On the Feast of the Epiphany VII), 2; http://www.vatican.va/ spirit/documents/spirit_20000804_leone-magno_en.html (11/09/2013).

${ }^{31}$ Cf. Sermon XXIV, 1, p. 229.

${ }^{32}$ Sermon XXVI, 1, p. 232. 
retained their own proper character without loss"3: "the Word of GOD, Himself GOD, the Son of GOD who 'in the beginning was with GOD,' through whom 'all things were made' and 'without' whom 'was nothing made (Jn 1:1-3),' with the purpose of delivering man from eternal death, became man: so bending Himself to take on Him our humility without decrease in His own majesty, that remaining what He was and assuming what He was not, He might unite the true form of a slave to that form in which He is equal to GOD the Father, and join both natures together by such a compact that the lower should not be swallowed up in its exaltation nor the higher impaired by its new associate. Without detriment therefore to the properties of either substance which then came together in one person, majesty took on humility, strength weakness, eternity mortality." ${ }^{34}$

Pope Leo uses almost poetic metaphors to express the greatness of the mystery of the Nativity of Christ: "being invisible in His own nature He became visible in ours, and He whom nothing could contain, was content to be contained: abiding before all time He began to be in time: the LORD of all things, He obscured His immeasurable majesty and took on Him the form of a servant: being GOD, that cannot suffer, He did not disdain to be man that can, and immortal as He is, to subject Himself to the laws of death." 35

The Incarnation was the only way of freeing men's minds taken captive by the devil from the abyss of death, as in order for the reconciliation with God to be possible "a Victim had to be offered for our atonement Who should be both a partner of our race and free from our contamination."36 This way all men of all times can attain salvation.

Celebrating the Nativity of the Saviour, we celebrate the beginning of our own lives as well: "For the birth of Christ is the source of life for Christian folk, and the birthday of the Head is the birthday of the body. [...] as the entire body of the faithful [...] is crucified with Christ in His passion, raised again in His resurrection, and placed at the Father's right

\footnotetext{
${ }^{33}$ Cf. Sermon XXIII, 2, p. 226.

${ }^{34}$ Sermon XXI, 2, p. 220.

${ }^{35}$ Sermon XXII, 2, p. 222.

${ }^{36}$ Sermon XXIII, 3, p. 227.
} 
hand in His ascension, so with Him are they born in this nativity." ${ }^{37}$ We can therefore concur with God in the act of redemption, wanting what $\mathrm{He}$ wants, rejecting and condemning what He rejects and condemns, with the strength of His power and not our own. ${ }^{38}$ That is what makes Christians "a chosen race, a royal priesthood, a holy nation, a people of his own" (1 Pet 2:9), the foundation of which is Christ himself, the impregnable rock in which they were reborn through water and the Holy Ghost. ${ }^{39}$ The birth of the Maker born of the Virgin's womb Pope Leo compares to the rebirth of each believer in the sacrament of baptism, when "the power of the Most High and the overshadowing of the Holy Spirit, which worked that Mary gave birth to the Saviour, also worked that water regenerate the believer." ${ }^{\text {"0 }}$

\subsection{Adoration, Imitation and the Ongoing}

Growth in the Grace of the Lord's Nativity

Apart from all the afore - mentioned topics that Pope Leo touched on in his sermons, at the end of each sermon he drew practical conclusions being indications for Christians' lives. At the end of Sermon XXI he remarks that since Christians became partners in the Divine nature of Christ, they should refuse to return to the old baseness by degenerate conduct. ${ }^{41}$ He reminds that by the mystery of Baptism man was made a temple of the Holy Ghost and part of the Body the Head of which is Christ himself. That is why his actions should reflect the dignity to which he was raised. A Christian needs to adore and follow his Master, and subsequently raise in the mercy given to him through the Mystery of the Incarnation.

Verbs like honorare, venerari, adorare are used very often by Leo the Great with reference to Christ, reminding that every knee will bend at the sound of His name and, "et omnis lingua confiteatur quoniam Iesus in gloria est dei patris, indesinenter tamen ipsum partum salutiferae uirginis

\footnotetext{
${ }^{37}$ Sermon XXVI, 2, p. 233.

${ }^{38}$ Cf. ibidem 4, p. 234.

${ }^{39}$ Cf. Sermon XXIV, 6, p. 231.

${ }^{40}$ Sermon XXV, 4.

${ }^{41}$ Cf. Sermon XXI, 3, p. 221.
} 
adoramus, et illam uerbi et carnis indissolubilem copulam non minus suscipimus in praesepe iacentem, quam in throno paternae altitudinis consedentem." ${ }^{22}$ The Incarnate Word is adored in the same way both on His Father's right hand and in the manger. That is why Leo finishes his sermon with the following appeal: "Honoretur in infantia sua dominus, nec ad deitatis referantur iniuriam exordia et incrementa corporea, quoniam naturae incommutabili nec addidit aliquid natura nostra, nec minuit, sed qui in similitudinem carnis peccati dignatus est hominibus esse conformis, in unitate deitatis patri permanet aequalis, cum quo et cum spiritu sancto uiuit et regnat in saecula saeculorum." ${ }^{\prime 3}$

Adoration of the Lord is every believer's task. Having discovered two Natures in the Lord, we should worship both the Word that became flesh in Christ and Man who became Christ In the Word. ${ }^{44}$ Similarly, in the sermon on the Feast of the Epiphany, Leo mentions the wise men, who "adore the Word in flesh, the Wisdom in infancy, the Power in weakness, the LORD of majesty in the reality of man." ${ }^{45}$ Therefore, he observes that a holy day of Lord's epiphany must be honoured not only with our faith, but our understanding as well. ${ }^{46}$ In the same way that a star more brilliant than the other stars aroused wise men to the recognition and adoration of the King of heaven and earth, ${ }^{47}$ the new Light will lead us to the adoration of God. ${ }^{48}$

Following Paul the Apostle, Saint Leo compares the birth of Christ as the Head to the Mystery of the Incarnation as the birth from flesh and relates this comparison to all the people who have been baptised: "For the birth of Christ is the source of life for Christian folk, and the birthday of the Head is the birthday of the body. Although every individual that is called has his own order, and all the sons of the Church are separated from one another by intervals of time, yet as the entire body of the faithful

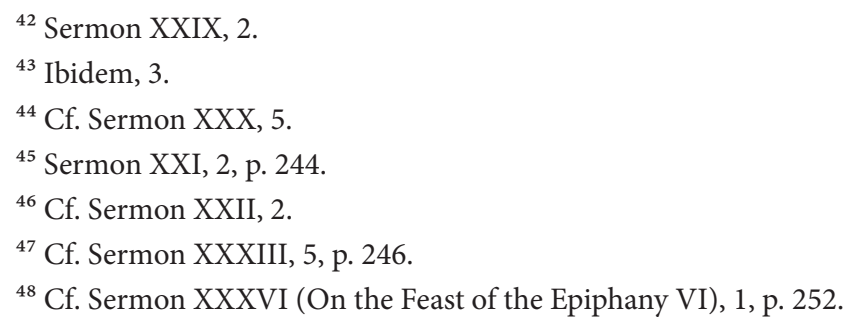


being born in the font of baptism is crucified with Christ in His passion, raised again in His resurrection, and placed at the Father's right hand in His ascension, so with Him are they born in this nativity." 9

Every believer, as well as the Lord's People as a whole, is born from the mystery of the Incarnation, that is why we may profit from acts of salvation if we use the Lord's teachings revealed to us in mysteries in our everyday lives. ${ }^{50}$ For we only develop spiritually in the Church if we learn from the works of our Lord, which have been offered to us as examples for imitation. Pope Leo reminds, that by the mystery of baptism man became the temple of the Holy Ghost and a member of the Body, the Head of which is Jesus Christ. Believer's conduct should reflect the dignity to which he was raised: "We should live in the humility and meekness of the Redeemer [...]. For in vein are we called Christians, if we are not imitators of Christ." ${ }^{51}$ The works of the Lord set an example for His disciples, who, having experienced God's great mercy, must be extremely careful not to be once more entangled in the errors which they have renounced. ${ }^{52}$ Believing in both the divinity and humanity of Christ we become true Christians, participate in the riches of His glory among the saints and regain the holy gift of infancy: "Consequently, dearly beloved, the whole learning of Christian wisdom consists not in abundance of words, not in cleverness at disputing, not in desire for praise and glory, but in a true and willing humility. This is what the Lord Jesus Christ chose and taught from within the womb of his Mother right up to his torment on the cross - by enduring everything with fortitude. When the disciples, as the Evangelist says, arguing among themselves as to "which one of them would be greater in the kingdom of heaven, [Jesus] called a little child and stood him in their midst and said: 'Amen, I say to you, unless you change yourselves and become like little children, you will not enter the kingdom of heaven. Whoever, therefore, humble themselves like this child will be the greater in the kingdom of heaven" (Mt 18:1-4). Christ loves the Childhood that he first took up in both soul and body. Christ loves childhood, the teacher

\footnotetext{
${ }^{49}$ Sermon XXVI, 2, p. 233.

${ }^{50} \mathrm{Cf}$. Sermon XXV, 5.

${ }^{51}$ Ibidem, 6.

${ }^{52}$ Cf. Sermon XXVII, 4, p. 238.
} 
of humility, the rule of innocence, the image of gentleness. Christ loves childhood, to which he directs the characters of older people, to which he brings back old age. Those whom he would raise up to an eternal kingdom he disposes to follow his own example."53

Saint Leo concludes that the earliest encouragement to live in the state of infancy we can find is in the words of Paul the Apostle: "in respect to evil be like infants" (1 Cor 14:20). Leo instructs us that it is not the immaturity and imperfections of childhood that we should be trying to return to, but the gentleness of behaviour and purity of intentions so typical for the youngest: "Non ergo ad ludicra infantiae et ad inperfecta nobis primordia reuertendum est, sed aliquid quod etiam graues annos deceat, inde sumendum est: Velox commotionum transitus, citus ad pacem recursus, nulla memoria offensionis, nulla cupiditas dignitatis, amor sociae communionis, aequalitas naturalis. Magnum enim bonum est nocere non nosse et ad maligna non sapere, quia inferre ac referre iniuriam, mundi huius prudentia est, nemini autem malum pro malo reddere, christianae est aequanimitatis infantia.". ${ }^{54}$

\section{Summary}

The Mystery of the Lord's Nativity in the Sermons of Leo the Great

Pope Leo the Great left a rich patrimony of letters and sermons, which were created as a result of his constant pastoral care for the community of Rome and for all the churches. The preserved collection contains about a hundred of sermons and about one hundred and fifty letters, all written in Latin. Among his sermons the ones that interest us the most are: on the Feast of the Nativity (11 sermons) and on the Feast of the Epiphany ( 8 sermons). On the basis of these source texts an attempt to elaborate on the main thoughts concerning the mystery of the Nativity is made. First the spiritual fruits of the

${ }^{53}$ Sermon XXXVII, 3; http://www.vatican.va/spirit/documents/spirit_20000804_leone-magno_en.html .

${ }^{54}$ Sermon XXXVII, 4. 
Mystery of Incarnation are discussed, then the Divine Mercy and lastly - the approach of the faithful to the mystery of the Lord's Nativity. Pope Leo summarises his teachings in the following way: "If we have recourse to that unutterable condescension of the Divine Mercy, whereby the Creator of men deigned to become man, by it we shall be raised to the nature of Him whom we adore in ours" (Sermon VIII on the Nativity).

\section{Keywords}

Nativity, mystery, humility, humbleness, light, joy

\section{Streszczenie}

\section{Misterium Bożego Narodzenia w mowach św. Leona Wielkiego}

Jednym z piewców misterium Bożego Narodzenia był papież, św. Leon Wielki. Znamy dobrze działalność św. Leona dzięki jego przepięknym kazaniom - zachowało się ich niemal sto, zapisanych wspaniałą i jasną łaciną, oraz dzięki jego listom - ok. stu pięćdziesięciu. Wśród jego kazań znajdujemy te, które najbardziej nas interesują: na Narodzenie Pańskie (11 mów) i na Objawienie Pańskie (8 mów). Z tego materiału źródłowego staram się przybliżyć główne myśli naszego autora dotyczące misterium Bożego Narodzenia. Najpierw zatrzymuję się na duchowych owocach Tajemnicy Wcielenia, następnie ukazuje przyjście Pana jako objawienie się Miłosierdzia Bożego, a przy końcu wskazuję na postawę, jaką człowiek powinien zająć wobec tajemnicy Bożego Narodzenia. Tak streszcza swoją naukę: „Uciekając się bowiem znowu do miłosierdzia Bożego - co w tak niewysłowiony sposób ku nam zstąpiło, że Stwórca ludzi zechciał stać się człowiekiem - poznajemy siebie w Tym, któremu Boską część oddajemy" (Na Narodzenie Pańskie 8).

\section{Słowa kluczowe}

Boże Narodzenie, misterium, pokora, uniżenie, światłość, radość 